\title{
底泥低圧処理土を利用した人工干潟の 環境改善効果の検証
}

\author{
片倉 徳男 $1 \cdot$ 村上 和男 $2 \cdot$ 今井 大蔵 3 - 国分 秀樹 4 \\ 1正会員 大成建設株式会社 技術センター（†245-0051 神奈川県横浜市戸塚区名瀬町344-1） \\ E-mail: norio.katakura@sakura.taisei.co.jp \\ 2フェロー 東京都市大学都市工学科（†158-8557 東京都世田谷区玉堤1-28-1） \\ E-mail: kmuraka@tcu.ac.jp \\ 3 芙蓉海洋開発株式会社＼cjkstart技術部（下111-0051 東京都台東区蔵前3-15-7） \\ E-mail: imai@fuyokaiyo.co.jp \\ 4三重県水産研究所（干517-0404 三重県志摩市浜島町浜島3564-3） \\ E-mail: kokubh00@pref.mie.jp
}

\begin{abstract}
沿岸域の環境保全対策の一環として進められている人工干潟の造成法として，浚渫へドロを干潟生物の 栄養源となる資源ととらえ，この脱水ケーキと海岸の砂質土を混合して造成する資源循環型人工干潟造成 工法が提案され，三重県英盧湾内で $7200 \mathrm{~m}^{2}$ の造成が行われた。筆者らは浚渫へドロを低圧縮力で固液分離 する低圧脱水処理システムを開発した。本報は本システムで処理した低圧処理土を資源循環型人工干潟へ 利用するための実用性について，32ケ月間にわたる現地実験で物理特性の変化，底生生物の生息量の面か ら検証するとともに，低圧処理土で構築した人工干潟の環境改善効果を評価した。実験より低圧処理土を 用いた資源循環型人工干潟は天然砂質土干潟に比べ大型のマクロベントスが生息しやすく，高い基礎生産 力を有することを確認した.
\end{abstract}

Key Words :man-made tidal flats, sediments, low pressure processing, circulation

\section{1. 研究の目的と背景}

干潟は, 多種多様な生物相が構築されるばかりでなく, 干満により乾燥・湿潤状態を繰り返すことで，土袞中の 微生物による有機物の酸化分解を促進寸る等, 沿岸域環 境の重要な位置を占めている. 近年，水質浄化や環境保 全の一環として，沿岸域での埋立てや人工護岸化等によ り減少した干潟を再生させる人工干潟の造成が進められ ている ${ }^{1)}$. 人工干潟の造成は，目標となる水深まで土砂， または浚渫へドロを敷設し，その表層を清浄な砂質土で 覆砂する工法がとられてきた。 しかし，干潟には有機物 を分解する多くのベントスが生息するため，適度に有機 物を含有する底質が望ましいことが報告されている ${ }^{2,3)}$ そこで，その有機物源として浚渫へドロを表層土に利用 する資源循環型の工法が提唱され，2004 年〜2005 年に 三重県英盧湾で本工法を用いた資源循環型人工干潟が造 成された ${ }^{4}$. この人工干潟は浚渫へドロを凝集沈殿処理 した後に，高圧フィルタープレスで固液分離した低含水 比 $(\omega=60 \%$ 以下 $)$ 脱水ケーキを用いている. 一般的に, 海底からポンプやグラブで浚渫されたへドロは, 最終的
に盛土等の再利用, あるいは処分場に埋立処理される. そのため, 高含水比の浚渫へドロを運搬可能な状態, あ るいは体積を小さくして処分費を抑制するために，フィ ルタープレスによる高圧縮力で $\omega=60 \%$ 程度まで固液分 離・脱水する処理方法が用いられてきた ${ }^{5}$ 。この, 固液 分離・脱水処理作業は浚渫事業費の約 $1 / 3$ 以上を占めて おり，コストダウンも望まれている，これに対して，資 源循環型人工干潟に浚渫へドロを利用する場合, 極端に 低含水比の脱水ケーキは不要で, 重機による移動が可能 で，人工干潟において泥水となって再分散しない性状を 確保できればよい. したがって，比較的高含水比の脱水 ケーキの利用が可能である. 筆者らは，このようなコン セプトにもとづき干潟土壤として利用可能な含水比まで 短時間で脱水・固液分離する方法として, 製紙スラッジ を主原料とする凝集材を利用する低コストの「低圧脱水 システム」を開発した ${ }^{9}$. しかし，低圧脱水システムで 処理した脱水ケーキを資源循環型人工干潟に利用寸るた めに必要な，生物生息機能，環境改善機能などの実用性 の評価は全くなされていない.

本研究は, 低圧脱水システムで固液分離・脱水処理を 


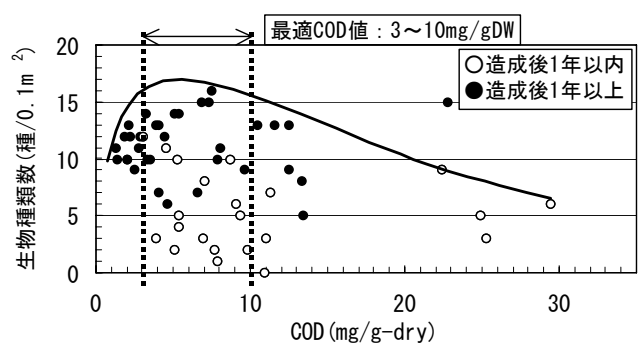

図-1 干潟生物量と $\mathrm{COD}^{8)}$

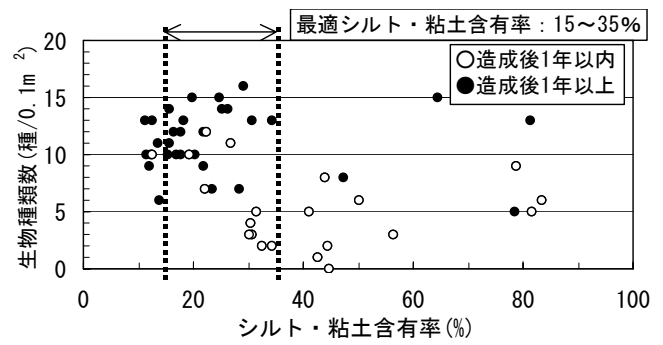

図-2 干潟生物量とシルト粘土含有率 ${ }^{8}$

した脱水ケーキ(以下，低圧処理土)を実海域の実験区に 敷設し, 約 2 年半にわたり物理性状の変化(シルト・粘 土含有量等の土質性状)，含有寸る有機物量の変化(底質 $\mathrm{COD}$ などの有機物量), 生物生息量の調査を実施し, 生 物生息機能を検証した．さらに，低圧脱水システムで処 理した浚渫へドロを利用した資源循環型人工干潟の底質 浄化機能に着目し，基礎生産量を評価し，人工干潟の環 境改善効果について検証した。

\section{2. 人工干潟への浚渫ヘドロの利用}

\section{(1) 資源循環型人工干潟の造成}

多種多様な生物が生息する干潟では，生息生物量は生 物の餌となる有機物やシルト・粘土含有量に依存するこ とが明らかになっている22,67). 図-1，図-2 は三重県英盧 湾に造成した浚渫へドロを利用した人工干潟における生 物量と有機物含有量の指標である底質 $\operatorname{COD}($ 化学的酸素 要求量), および, シルト・粘土含有量の関係を示して いる. 図-1 は干潟に生息する生物種類数が，有機物が ほとんど含まれない場合や過剩に含まれる場合は減少し， 生物の生息に適した範囲は3〜10 $\mathrm{mg} / \mathrm{gDW}$ であることを 示している. 同様に，図-2よりシルト・粘土含有量も 生物の生息に適した範囲は干潟土壌中のシルト・粘土含 有率が 15〜35\%となっている。 これらの知見をふまえ， 干潟生物が最も生息しやすいCOD とシルト・粘土含有 率を満たす高圧処理した脱水ケーキ(以下，高圧処理土) と清浄な砂質土を混合した資源循環型人工干潟 $\left(7200 \mathrm{~m}^{2}\right)$

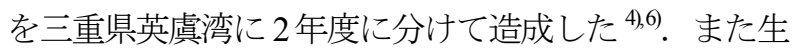
物の定着状況や干潟の浄化機能の効果を検証するために,

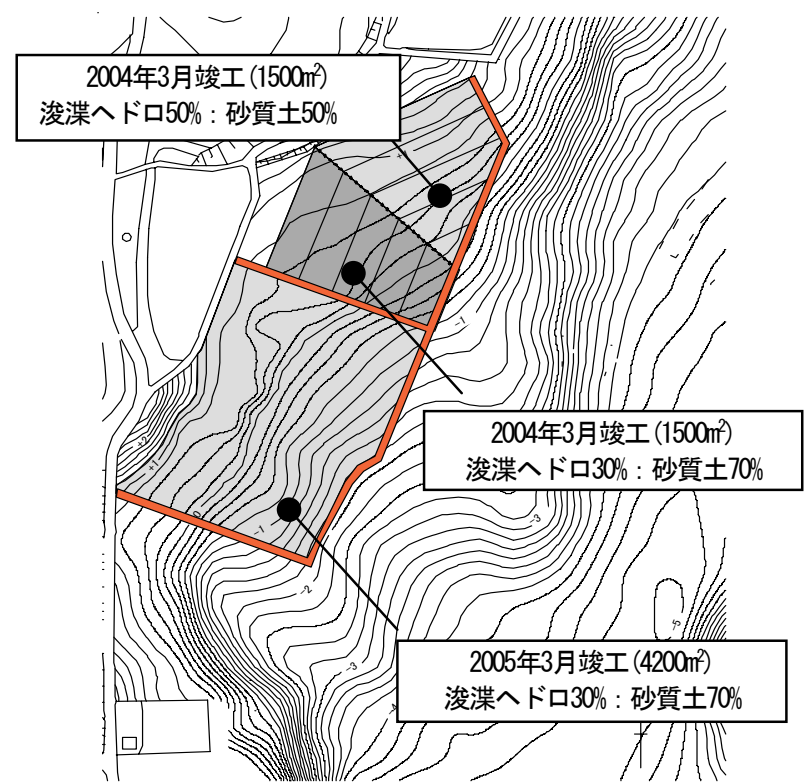

図-3 施工場所

2 種類の浚渫へドロの混合率で造成している．図-3に人 工干潟の施工年度と浚渫へドロと砂質土の混合率を示す。

\section{(2) 低圧脱水システムの概要}

一般的に，浚渫へドロや高濃度の濁水の処理は $\mathrm{PAC}(ホ ゚ リ$ 塩化アルミニウム)等の無機系凝集材に高分子 凝集材を添加した薬剤により固形分を凝集沈殿させ，沈 殿物を高圧フィルタープレス $(0.5 \mathrm{MPa})$ で脱水する処理方 法がとられている．これに対し低圧脱水システムは，製 紙工場から排出される製紙スラッジを主原料とする凝集 剂の特性を利用した新たな処理システムである。この凝 集剂は PAC を使用する場合に比へ，早期の凝集・沈降 特性と強固なフロックの形成が特長であり, 沈殿したフ ロックが強固で再溶解しにくい等の特徵がある ${ }^{9}$. 写真1 は浚渫へドロに凝集固化材を添加する前後の浚渫へド 口の状態を示寸．凝集固化材添加後に濁質成分が凝集沈 殿し上澄水と分離していることがわかる. 低圧脱水シス テムは，この凝集剤の早期の凝集固化性能を利用してい る. 写真-2 は新たに開発した薬剤の特徵を活かした低 圧脱水システムである。浚渫へドロに凝集材を添加し, 短時間で凝集・沈殿したフロックと上澄水を分離する一 次処理装置と，低い圧力 $(0.014 \mathrm{MPa})$ でポリエチレン製の メッシュベルトに挟み込んで分離し，含水率約 $150 \%$ の 脱水ケーキを排出寸る 2 次処理装置で構成している. 低 圧脱水システムは短時間の凝集・沈降特性を利用した装 置の小型化と，脱水装置の簡易化により，装置の設置面 積が従来の処理方法に比べ約 30\%，浚渫へドロの固液 分離・脱水処理コストが約 10-20\%低減可能なシステム である. 写真-3 に低圧処理土と，従来の処理法である 高圧フィルタープレスで処理した高圧処理土を示寸．低 圧処理土は，高圧処理土に比べ含水比が高いが，資源循 


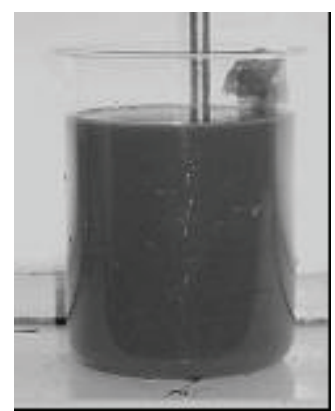

凝集固化材添加前(原泥水)

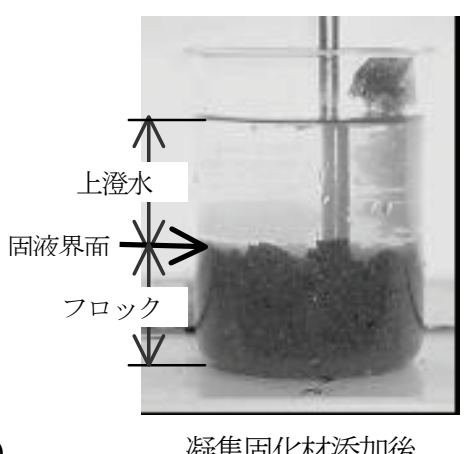

凝集固化材添加後
写真-1 凝集固化材添加前後の状態(凝集固化材添加量 3\%)

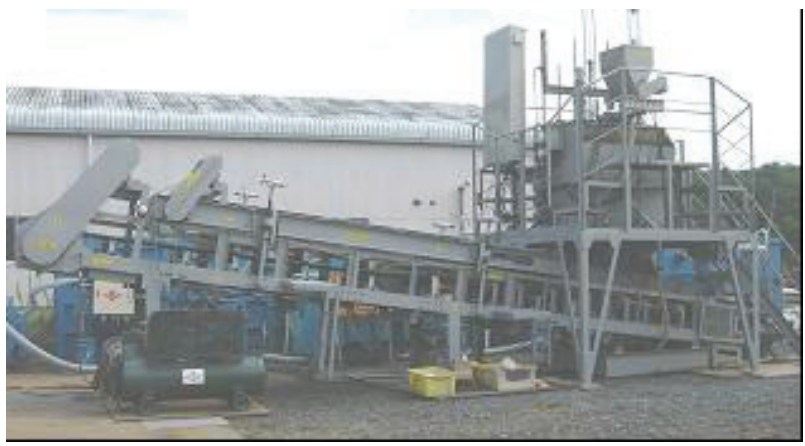

写真-2 低圧脱水処理装置 $\left(1.5 \mathrm{~m}^{3} / \mathrm{hr}\right.$ 仕様)

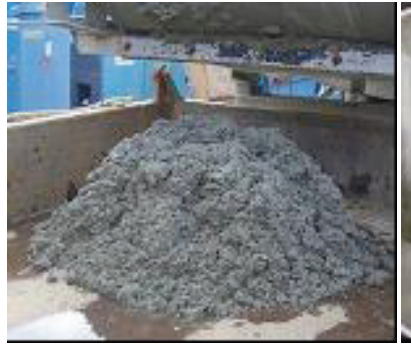

低圧処理土(含水比 $150 \%$ )

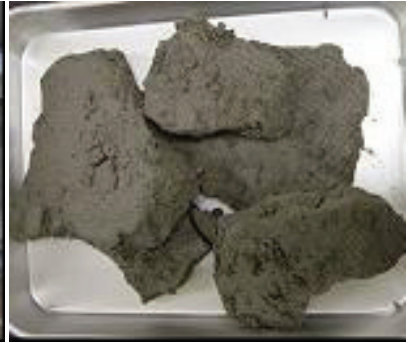

高圧処理土(含水比 $35 \%$ )
写真-3 脱水ケーキの外観

環型人工干潟で求められる「干潟造成地域までダンプ等 で搬送可能」，「砂質土と混合が可能」，「干潟で分 散・再溶出しない」などの機能を満たしている ${ }^{8}$.

\section{3. 人工干潟における低圧処理土の実用性検証}

\section{(1) 実験条件}

実験区の条件を表-1 に，配置を図-4 に示す．実験区 は三重県英盧湾に造成している高圧処理土で造成してい る資源循環型人工干潟の一部に設けた，実験区は，低圧 脱水システムで浚渫へドロを固液分離処理した低圧処理 土と有機物含有量が少ない現地の原地盤の砂質土を 7 : 3 の割合で混合した実験区 E1，後述する粒状化処理した 低圧処理土と砂質土を $7: 3$ の割合で混合した実験区 E2, 比較対照として清浄な砂質土の夕の実験区 E3 の 3 種類
表-1 実験区と計測点の条件

\begin{tabular}{|c|c|c|}
\hline & 名称 & 干潟土袞の内容 \\
\hline 実 & E1 & 低圧処理土と砂質土を 7:3で混合 \\
\hline 験 & E2 & 低圧処理土(粒状化)と砂質土を 7:3 で混合 \\
\hline 区 & E3 & 砂質土 100\% \\
\hline $\begin{array}{l}\text { 計 } \\
\text { 測 }\end{array}$ & B3 & $\begin{array}{l}\text { 資源循環型人工干潟 } \\
\text { 高圧処理土と砂質土を } 7: 3 \text { で混合 }\end{array}$ \\
\hline 点 & $\mathrm{C} 2$ & 天然砂質土干潟(基礎生産量評価用) \\
\hline
\end{tabular}

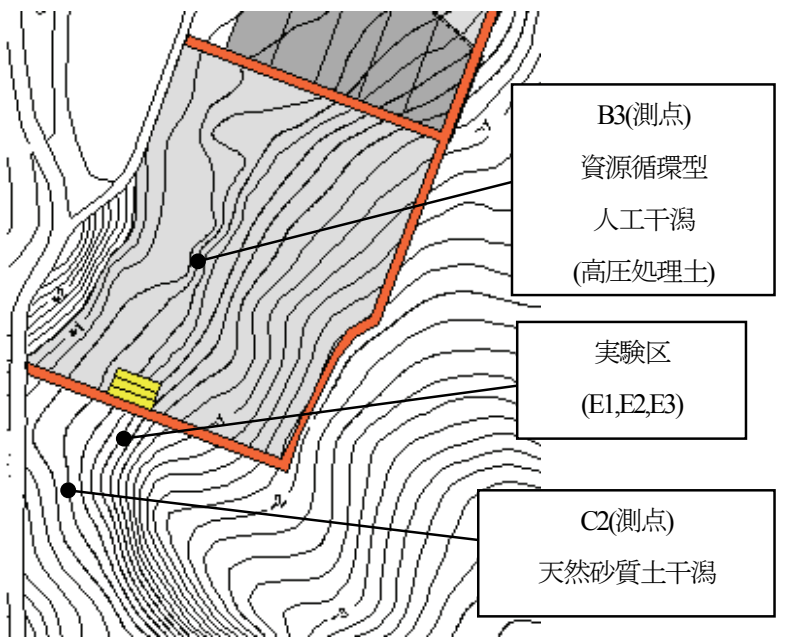

図-4 実験区の配置

の実験区で行った３つの実験区，高圧処理土で造成し ている資源循環型人工干潟内の測点(B3)，資源循環型人 工干潟に隣接する天然砂質土干潟(C3)を計測点とした. このうち C3 は干潟の基礎生産量の評価に用いた。 これ らの計測点で, 物理性状(シルト・粘土含有量), 有機物 量(底質 COD, 含水率, 強熱減量, 酸化還元電位, $\mathrm{pH}$, TOC，T-N，AVS，クロロフィル量)，生物生息量を評価 して実用性を検討することを目的とした。これらの実験 区と計測点で底質，マクロベントス調査を，年 4 回の頻 度で 32 ケ月間行った。

\section{（2）低圧処理土と砂質土の混合}

低圧処理土を用いた実験区 E1，E2 の土畩は，低圧処 理土と原地盤の砂質土の混合に写真-4 に示寸ドライブ ミキシング装置を使用した混合方法を用いた。これは高 圧処理土を用いた施工済夕の資源循環型人工干潟の造成 法と同じ方法である。なお，高圧処理土は含水比が低い ため写真-3 に示すような塊である.これを砂質土と混 合した場合，直径 $5 \mathrm{~cm}$ 程度の大きな塊の状態で砂質土 内に分散するケースが見られた，栄養塩の供給源として の利用を考えた場合，極力均一に分散することが望まし い，そこで，低圧処理土をより均一に分散させるため， 低圧処理土を直径 $6 \mathrm{~mm}$, 長さ $3 \mathrm{~cm}$ に粒状化処理装置で 処理して，ペレット状に成形したのち砂質土と混合した 実験区E2 設定した。

低圧処理土と砂質土の混合は資源循環型人工干潟の造 成に併せて行い，低圧処理土と砂質土の混合比率は人工 


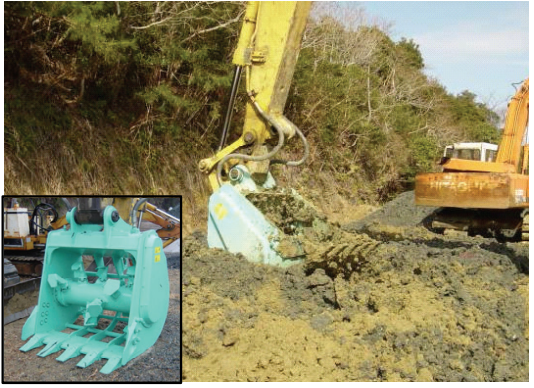

写真-4 ドライブミキシング装置と混合状況

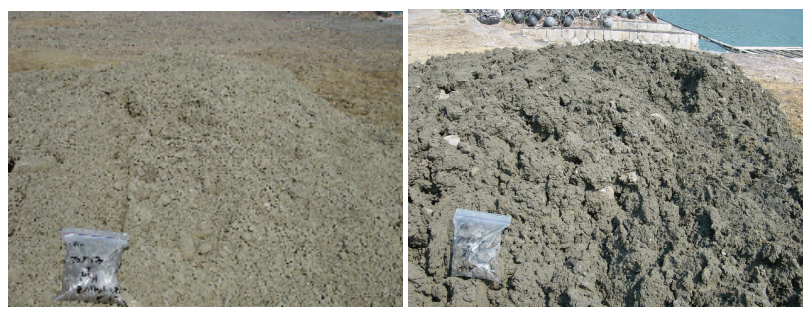

E1 : 低圧処理土+砂質土 $\mathrm{E} 2$ :低圧処理土(粒状化処理)+砂質土

写真-5 低圧処理土と砂質土の混合状態

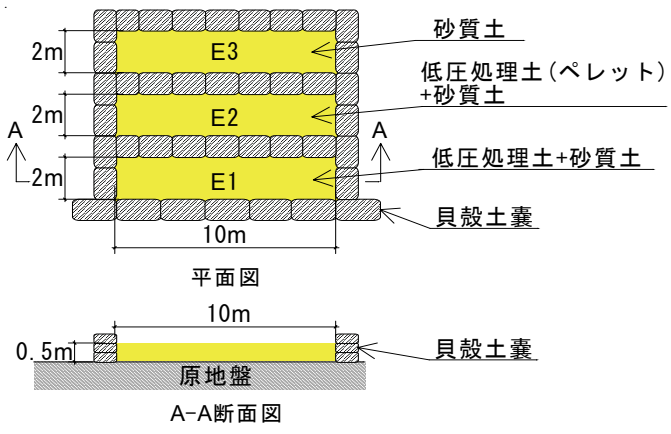

図-5＼cjkstart実験区配置図

干潟と同じ低圧処理土 : 砂質土=7 : 3 とした. 写真-5 は 砂質土と低圧処理土の混合状態を示す.

\section{(3) 実験区の概要および調査方法}

\section{a)構造と施工}

図-5 に実験区の平断面図を示す．実験区は平成 17 年 3 月に施工した。外周部を貝殻廃棄物を充填した土囊(貝 殼土囊)で仕切り，1つの実験区当たり $10 \mathrm{~m} \times 2 \mathrm{~m}=20 \mathrm{~m}^{2}$ と して汀線に直角に並べた. この実験区にドライブミキシ ング装置で混合した各実験区の材料をクレーン付台船に より造成厚さ $50 \mathrm{~cm} の$ 厚みとなるように投入した。

\section{b) 材料の性状}

表-2 に各実験区と比較計測点に敷設した材料の性状 を示寸．資源循環型人工干潟の設計值に対し低圧処理土 を用いた E1，E2 のシルト粘土含有量，底質 COD をほ ぼ満足している。このうち粒状化処理した E2 の底質 COD が E1 に比べ 3mg/g-dry 少ない。これは粒状化処理 時に間隙水が脱水され，間隙水中の有機物成分が除去さ れたためである.
表-2 材料の性状

\begin{tabular}{|c|c|c|c|c|}
\hline \multicolumn{2}{|c|}{ 実験区 } & \multirow{2}{*}{$\begin{array}{c}\text { 含水比 } \\
(\%)\end{array}$} & \multirow{2}{*}{$\begin{array}{l}\text { シルト・粘 } \\
\text { 土含有率(\%) }\end{array}$} & \multirow{2}{*}{$\begin{array}{l}\text { 底質 COD } \\
\text { (mg/g-dry) }\end{array}$} \\
\hline 名称 & 内容 & & & \\
\hline E1 & $\begin{array}{c}\text { 低圧処理土 } \\
+ \\
\text { 砂質土 }\end{array}$ & 33.4 & 35.6 & 8.9 \\
\hline E2 & $\begin{array}{c}\text { 低圧処理土 } \\
\text { (粒状化処 } \\
\text { 理) } \\
+ \\
\text { 砂質土 }\end{array}$ & 33.8 & 28.0 & 5.9 \\
\hline E3 & 砂質土 & 22.4 & 16.9 & 2.4 \\
\hline B3 & 高圧処理土 & 26.5 & 35.5 & 6.2 \\
\hline \multicolumn{2}{|c|}{ 設計值 } & - & $30-50$ & $2.5-5.5$ \\
\hline
\end{tabular}

\section{表-3 調查項目}

調查項目

\begin{tabular}{c|l}
\hline \multicolumn{1}{c}{ 調査項目 } \\
\hline & 粒度分布(JS A1204), 底質 COD(底質調査法 II.20),含水率 \\
底質 & (底質調查法 II.3),強熱減量(底質調査法 II.4),酸化還元電位 \\
& (白金電極法),pH(ガラス電極法), TOC, T-N(CHN コーダ \\
& 一),AVS(検知管法), クロロフィル量(海洋観測指針 6.3.3) \\
\hline 底生生物 & マクロベントス個体数, 種類数, 湿潤重量 \\
\hline
\end{tabular}

\section{c)調査方法}

本実験では低圧処理土の資源循環型人工干潟における 実用性を評価するために，底質 COD，シルト粘土含有 率，マクロベントスを評価項目とした。実験区および B3 測点において, 直径 $10 \mathrm{~cm}$, 長さ $40 \mathrm{~cm}$ のコアパイプ を使用して柱状試料を採取した。採取した試料は $10 \mathrm{~cm}$ の層別に分取し, 各層分を混合して底質分析に供した. マクロベントスはハンドグラブ $\left(0.2 \mathrm{~m}^{2}\right)$ 及びコアパイプ $\left(0.1 \mathrm{~m}^{2}\right)$ で表層から深さ $20 \mathrm{~cm}$ までの底質を採取し, 出現 種類, 出現個体数, 湿潤重量を分析した. 表-3に調査 項目を示す.

\section{(4) 物理特性の変化}

実験区 E1，E2 は，多くのベントスを生息させるため 有機物を混合している. 人工干潟ではベントスが定着す るまで有機物量の変化が生じないことが望ましい. そこ で，底質の有機物含有量を評価した。

\section{a) シルト・粘土含有量}

図-6にシルト・粘土含有率の鉛直分布の変化を示す. 図中の赤線は各実験区の施工時のシルト粘土含有率であ る. 低圧処理土を用いた E1 は施工 2 ケ月後に干潟表面 から $20 \mathrm{~cm}$ の深さ以深で最大 $50 \%$ のシルト粘土含有率を 示しているが，施工 8 ケ月後以降は全層において約 25 〜35\%の範囲を維持している. また E2 も施工 2 ケ月後 は 30〜 50\%の範囲で各層のシルト粘土含有量が変動して いるが 8 ケ月目以降は，E1 と同様に約 20～30\%の範囲 となった。国分ら(2005)によれば，水中にまき出した高 圧処理土と砂質土を水中で攪拌混合した場合，攪拌によ り高圧処理土が再泥化して，表層に比重の軽い細粒分， 下層に粗粒分が集積する分級が生じることを報告してい 
る ${ }^{4)}$. 本実験区は水中での攪汼は行わずに，陸上で混合 した土壤を水中へ撒き出している。この結果，E1，E2 では施工 2 ケ月後にシルト粘土含有率の変動量は $20 \%$ に とどまり，分級が生じにくい傾向であることを確認した

B3 は高圧処理土を用いた実験区であるが，干潮時に 施工したため水中での攪拌を行っておらず，E1，E2 と 同様にシルト粘土含有率の変動量は $20 \%$ 以内にとどまっ ている.しかし，施工 8 ケ月後以降のシルト粘土含有率 をみると，E1，E2 は 10\%以内の変動幅であるのに対し B3 は 20\%程度と大きい. これは塊状に存在する高圧処 理土を分析に供しているためと考えられる. 一方，E1， E2 は全層において低圧処理土が分散して存在するとと もに再泥化もみられず，32 ケ月にわたり安定したシル 卜粘土含有量を維持した. さらに，施工 27 ケ月後の E1, E2 を比較すると，粒状化処理を施した E2 は 26-33\%と 7\%の変動幅であるのに対し E1 は干潟表面に近いほどシ ルト粘土含有率が減少する傾向を示した。 これは海水の 波浪や流れの影響を受けやすい干潟表面付近のシルト粘 土が，E2に比べE1 で，より減少しやすいことを示して いる. このれらの結果から，低圧処理土の粒状化処理が より安定したシルト粘土含有率を維持できることを示し ている.

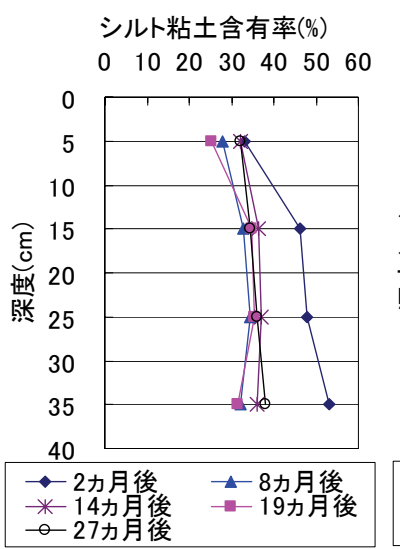

E1

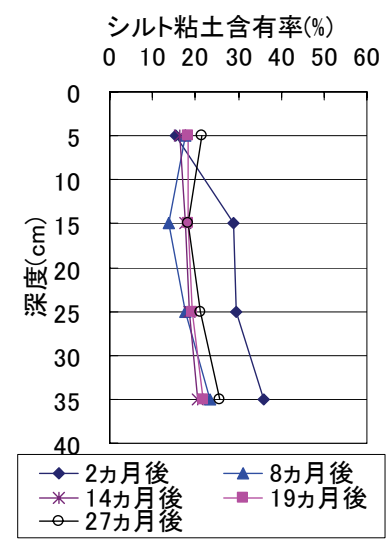

E3

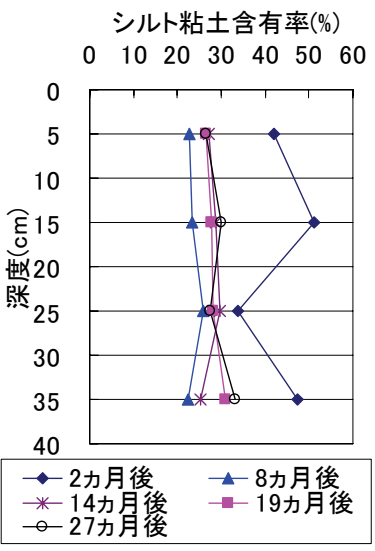

E2

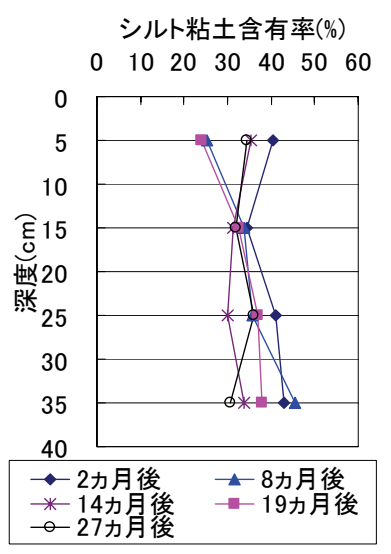

E4

図-6 シルト粘土含有率の鉛直分布の変化

\section{b) 底質 COD}

干潟内で採取した柱状試料を $10 \mathrm{~cm}$ の層別に分取し， 干潟表面から $10 \mathrm{~cm}$ の表層試料，干潟表面から 30～40cm の試料を下層試料として分析した，底質 COD の経時変 化を図-7 に, 各実験区の底質 COD の平均值と最大, 最 小值を表-4 に示す. 底質 COD の極端な変化(増加・減 少)は干潟に生息する底生生物量の減少を招くが ${ }^{26}$, 底 質 COD の変動量((MAX)-(MIN))は E1, E2 ともに 0.4-0.9 mg/g-dry と B3 と同レベルを維持している. また，シル 卜粘土含有率が安定していることと同様に，底質 COD は施工時の状態を施工後 29 ケ月経過後も維持した. な お，砂質土を用いた E3 は標準偏差は 0.3〜 $1.2 \mathrm{mg} / \mathrm{g}$ と低 圧処理土を用いた実験区と同様であるが，施工時の底質 COD が $2.4 \mathrm{mg} / \mathrm{g}$ と低く, 底生生物の生息には適した環境 ではないと考えられる。

\section{(5) 出現生物の変化}

\section{a) マクロベントス個体数}

マクロベントスの出現個体数は，採取装置(ハンドグ ラブ及びコアパイプ)の面積あたりの個体数を $1 \mathrm{~m}^{2}$ あた りに換算して算出した. 図-8 に施工後の経過月数とマ クロベントスの個体数の変化を示す，E1，E2，E3 では 施工 2 力月後は 50 個体 $/ \mathrm{m}^{2}$ 以下の個体数にとどまってい るが，その後は秋季加ら冬季に加て増加し，2 年目の 夏季に低下する傾向を示した。 また，高圧処理土を用い た B3 に比べ，施工後 1 年間は実験区における個体数が 増加しているが，2 年目の夏季(17 ケ月後)以降は, B3 と の顕著な差はみられなくなった．造成後 1 年目の個体数 の増加は，底質表面を介して浚渫へドロから供給される

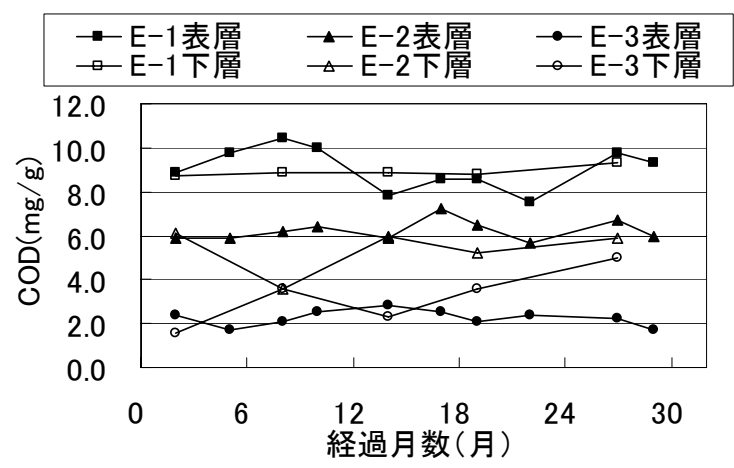

図-7 底質 $\mathrm{COD}$ の変化 $(\mathrm{mg} / \mathrm{g})$

表-4 底質 $\mathrm{COD}$ の平均, 最大, 最小值 $(\mathrm{mg} / \mathrm{g})$

\begin{tabular}{c|c|c|c|c|c|c}
\hline & 材料性状 & & 平均 & MAX & MIN & 標準偏差 \\
\hline \multirow{2}{*}{ E1 } & \multirow{2}{*}{8.9} & 表層 & 9.1 & 10.4 & 7.5 & 0.9 \\
\cline { 3 - 7 } & & 下層 & 8.9 & 9.3 & 8.7 & 0.2 \\
\hline \multirow{2}{*}{ E2 } & \multirow{2}{*}{5.9} & 表層 & 6.2 & 7.2 & 5.7 & 0.4 \\
\cline { 3 - 7 } & 下層 & 5.4 & 6.1 & 3.6 & 0.9 \\
\hline \multirow{2}{*}{ E3 } & \multirow{2}{*}{2.4} & 表層 & 2.2 & 2.8 & 1.7 & 0.3 \\
\cline { 3 - 7 } & & 下層 & 3.2 & 5.0 & 1.6 & 1.2 \\
\hline B3 & 6.2 & 表層 & 6.5 & 7.7 & 5.5 & 0.8 \\
\hline
\end{tabular}


有機物による効果と考えられる．低圧処理土のうち E1 と E2 を比較すると, 粒状化処理を施した E2 が E1 に比 べると個体数が多くなる傾向である，また，高圧処理土 $\mathrm{E} 3$ ，低圧処理土 $\mathrm{E} 1 ， \mathrm{E} 2$ は，ともに 2 年目以降の夏季の 個体数が減少している. これは実験区を D.L.- $0.5 \sim 0.0 \mathrm{~m}$ に設定しており，夏季は干出及び低水深時の水温上昇の 影響を受け，個体数が減少したと考えられる．また，

E1，E2，E3 では出現する生物相が变化し個体数が 2, 3 年目は減少した. 施工後 1 年目の個体数の増加は主に腹 足類の増加によるものである. 2 年目以降は甲殼類, 二 枚貝のツキガイやスダレガイ類が増加している.

\section{b) 出現種類数}

マクロベントスの出現種類数は, 採取装置(ハンドグ ラブ及びコアパイプ)の面積あたりの種類数をそのまま 用いた．図-9 に施工後の経過月数とマクロベントスの 出現種類数の変化を示寸. 出現個体数と同様に施工 2 力 月後は出現する生物数が 10 種類 $/ \mathrm{m}^{2}$ 以下と少なく, 5 ケ 月目以降加種類が増加し始めている. 施工後 8 个月目 以降は, 個体数が増加する秋季に出現生物種類数もピー クを示している. 出現個体数が施工から 2,3 年目に減 少する傾向を示すのに比べ, 出現種類数は 2 年目の秋に 50 種類以上に達し, その後も 30 種類以上の種類数て推 移している.また，多毛類の出現個体数が減少し，二枚 貝類や甲殼類の増加がみられはじめており，このことは， 実験区に出現する生物相が時間経過とともに多様化して いることが考えられる.

\section{c)生物量}

図-10 にマクロベントスの湿重量を出現個体数で除し

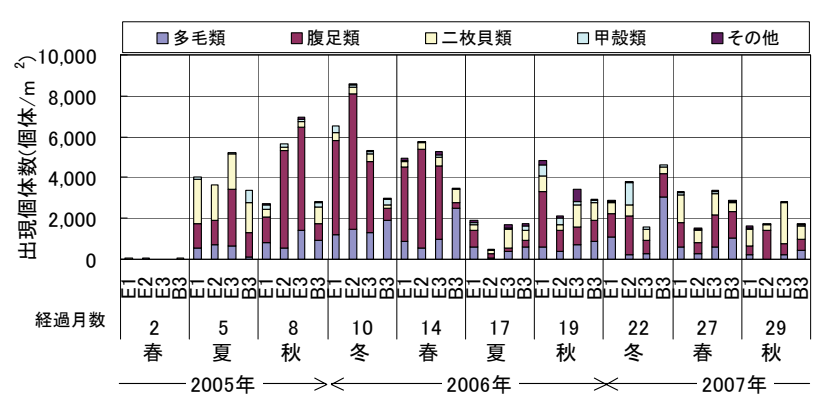

図-8 マクロベントス個体数(横軸の数字は施工後の月数)

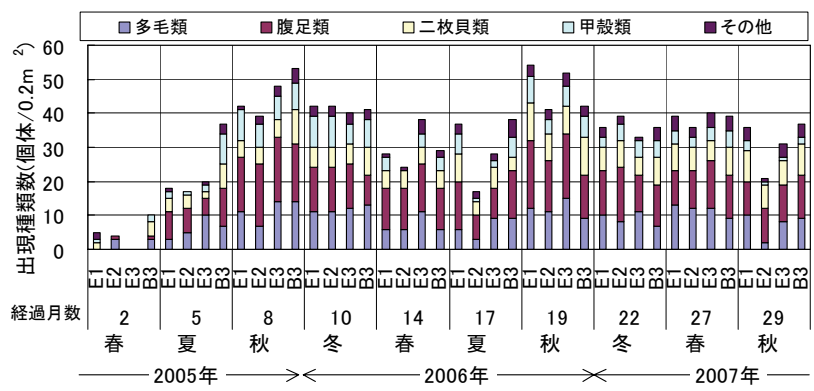

図-9 マクロベントス出現種類数(横軸の数字は施工後の月数)
た分類別の平均湿重量の変化を示す. 出現個体の湿重量 は, 2 年目までは甲殼類が最も大きく, 最大約 $0.6 \mathrm{~g}$ 個体 である.また 1 年目に多量の個体数が観察された多毛類 のでは非常に小さな個体である. 2,3 年目も甲殼類の 重量にはあまり大きな変化がみられない. しかし， 2 年 目以降に個体数が減少傾向である多毛類では, 約 $0.1 \mathrm{~g} /$ 個体以上に大型化している. この結果から，低圧処理土 を用いた E1，E2 では，生息する生物のうち特に多毛類 が大型化，または成長する傾向が明らかになった．国分 らは，高圧処理土を用いた小規模干潟 $\left(25 \mathrm{~m}^{2}\right)$ と大規模干 潟 $\left(3000 \mathrm{~m}^{2}\right)$ におけるマクロベントスの変遷について, 小 規模干潟では生物相の安定に約 1 年半を要することを報 告している 9) 10). 低圧処理土を用いた E1，E2 では季節 的な変動がみられるものの施工後 14 ケ月以降に個体数 1000 個 $/ \mathrm{m}^{2}$ 以上，個体数 30 種類以上を維持しており, 高 圧処理土を用いた小規模干潟に比べ，より多くのマクロ ベントスが生息する環境を創出できることが明らかにな った.

\section{(6) 低圧処理土の実用性}

2 年半にわたる実験から, 資源循環型の人工干潟に低 圧処理土の実用性を検討寸る。

低圧処理土を用いた人工干潟は，資源循環型人工干潟 の設計指標としたシルト粘土含有率, 底質 $\mathrm{COD}$ を 2 年 半以上にわたり維持していることを確認した. 特に従来 の高圧処理土を使用した場合に比べ，水中での施工でも 再泥化の抑制と均一な分散性を保ち，人工干潟の造成に 適用できることを確認した. さらに, 高圧処理土に比べ 軟弱な低圧処理土の粒状化処理は, 移動時のハンドリン グが向上するとともに，干潟生物の生息に適したシルト 粘土含有率と底質 COD をより安定した状態で維持でき た. また，人工干潟に生息するマクロベントスに着目す ると，低圧処理土を用いた実験区では施工後 5 ケ月目以 降から個体数, 種類数が大幅に増加し, 施工後 19 ケ月 経過後の 2 年目秋には 50 種類以上の生物が確認でき, 多様化した生物相の構成を確認した. また, 季節的な変 動がみられるものの 1 個体あたりの重量が増加しており, 低圧処理土を用いた資源循環型人工干潟は，大型の生物 が生息する環境を創出できることが明らかになった。

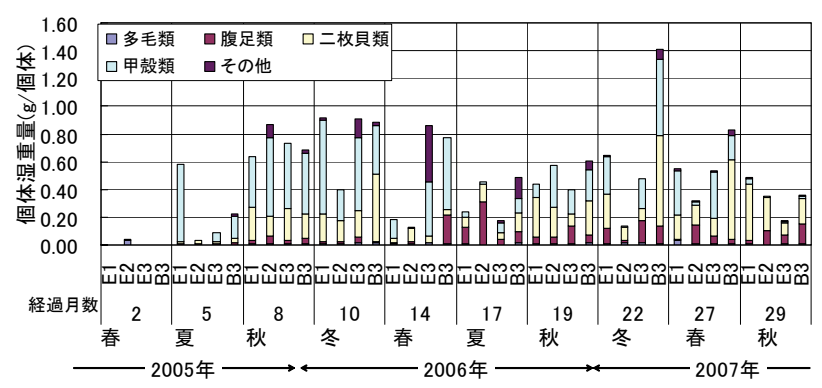

図-10 マクロベントス個体平均湿重量 


\section{4. 浄化機能の評価}

\section{(1) 実験の概要}

多種多様な生物相が構築される人工干潟は，沿岸域の 生態系として重要な位置を占める．干満により好気・嫌 気環境が繰り返される干潟では，マクロベントスによる 有機物の分解だけでなく，底質表面に生息する微細藻類 の光合成による酸素供給，バクテリアやベントスによる 有機物の分解に伴う酸素消費や硝化・脱窒等が行われて いる. そこで，これらの機能に着目し，低圧処理土を用 いた人工干潟と天然干潟における浄化機能の評価を行っ た．実験は図-4 に示したように，低圧処理土と砂質土 を混合した実験区 E1(低圧処理土+砂質土)，E2(粒状化低 圧処理土+砂質土), 砂質土の実験区 E3 に加え, 天然の 砂質土干潟である C2 測点を対象区として設定した．表5 に調查内容を示す．実験は水温の上昇する夏季と冬季 に，チャンバーを用いた酸素消費速度の測定を行い，干 潟の基礎生産量を算出した. そして, 酸素消費速度に加 え, 溶出成分, 底質成分の調查結果と併せて, 干潟の浄 化機能を評価し，環境改善効果を検証した。

\section{(2) 調査項目之調査方法}

\section{a) 酸素消費速度調査}

実験区 E1，E2，E3 及び対象区として C2(DL-0.5m)に 図-11 に示寸ようなチャンバー $(\Phi 150 \mathrm{~mm} \times 340 \mathrm{~mm})$ をセッ 卜する. チャンバー下部を底質に $20 \mathrm{~cm}$ 挿入し，内部を 攪拌モーターで底質を巻き上げないように攪拌しながら， $\mathrm{DO}$ センサーで 0.5 秒毎に DO を計測する. 1 回の DO 計 測は 2 時間とし，明暗それぞれの条件で計測を行った。

\section{b) 溶出成分 · 底質間隙水調査}

直径 $10 \mathrm{~cm}$ 長さ $30 \mathrm{~cm}$ のアクリルコアを海底に $20 \mathrm{~cm}$ 捙 入し，設置時の海水と 4 時間放置後の上澄水と底質を採

表-5 調査内容

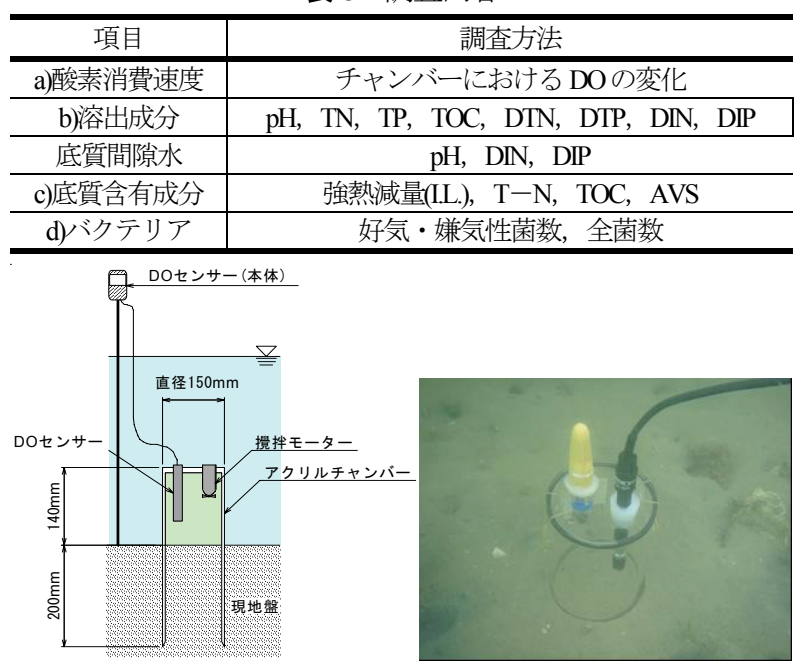

図-11＼cjkstart酸素消費速度計測装置
取した。溶出成分として上澄水を採取し，WatmanGF/F 濾紙を用いて濾別し，濾過水と末濾過水をそれぞれ分析 した，底質は溶出成分に最も影響すると考えられる表層 から $1 \mathrm{~cm}$ の試料を採取後，遠心分離した上澄水を Watman GF/F濾紙を用いて濾別し底質間隙水とした.

c)マクロベントス

酸素消費量計測完了後，チャンバー底部にゴム栓をし て底質表層から深さ $20 \mathrm{~cm}$ の底泥を採取した。採取した 底泥を $1 \mathrm{~mm}$ メッシュのふるいで分画してから，残留物 を現地でホルマリンで固定し，出現種・個体数・種類 数・湿重量を同定・定量した.

d)バクテリア

直径 $10 \mathrm{~cm}$ のアクリルコアを海底に挿入し，底質表層 から約 $5 \mathrm{~mm} ， 5 \sim 20 \mathrm{~mm} ， 20 \sim 50 \mathrm{~mm}$ の底質を採取した。 各層の底質について，底質分解に寄与寸る好気・嫌気性 菌数および全菌数を，好気・嫌気性菌は MPN 法で，全 菌数は DAPI法で定量した。

\section{(3) 計測結果}

\section{a)酸素消費速度の変化}

図-12 にチャンバー内の初期 DO を基準としたチャン バ一内における $\mathrm{DO}$ の変化の一例(E1；夏季，冬季)を示 す．夏季の明条件は植物プランクトンの活発な光合成に より $\mathrm{DO}$ が増加する. 逆に, 暗条件では植物プランクト ンからの生産は無くなり，底泥による酸素の消費が行わ れるため DO は減少する。一方，冬季の明条件は底泥に よる消費量が植物プランクトンの生産量を上回り DOが

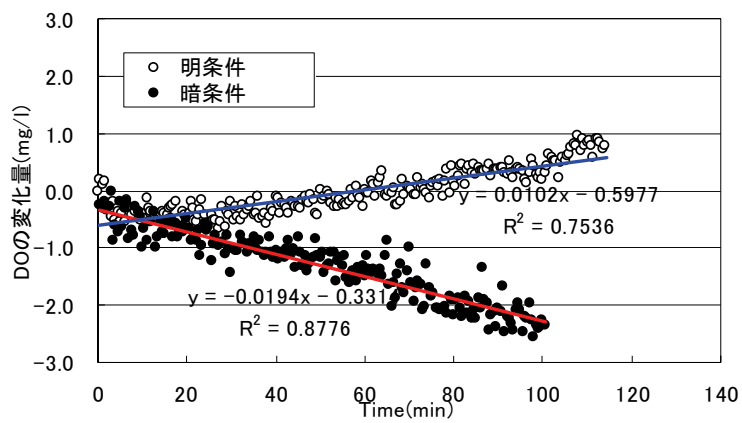

図-12(a) チャンバー内の DO の変化(夏季 : E1)

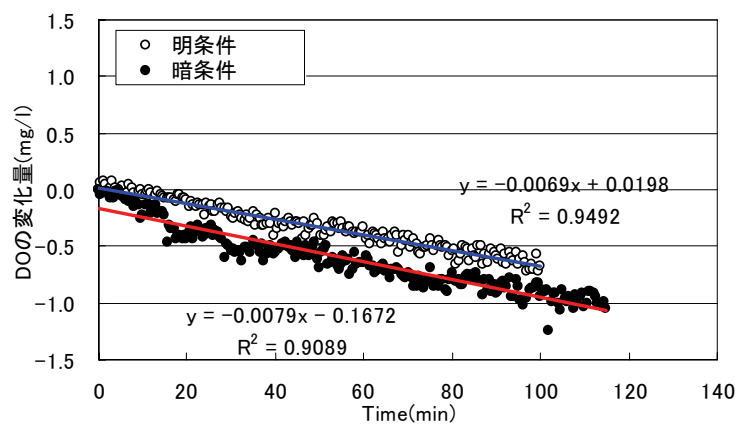

図-12(b) チャンバー内の DOの変化(冬季 : E1) 
減少している. 底質の酸素消費速度 $Q\left(\mathrm{mgO} / \mathrm{m}^{2} / \mathrm{hr}\right)$ は, 植物プランクトンの影響を受けない暗条件のチャンバー の酸素消費速度 $Q d\left(\mathrm{mgO} / \mathrm{m}^{2} / \mathrm{hr}\right)$ から, バックグラウンド である暗条件下における水中の有機物の分解による酸素 消費速度 $Q b\left(\mathrm{mgO} 2 / \mathrm{m}^{2} / \mathrm{hr}\right)$ を差し引いた式(1)で算出した.

$$
Q=Q d-Q b
$$

$Q\left(\mathrm{mgO} 2 / \mathrm{m}^{2} / \mathrm{hr}\right)$ : 底質の酸素消費速度

$Q d\left(\mathrm{mgO} 2 / \mathrm{m}^{2} / \mathrm{hr}\right)$ : 暗条件下の酸素消費速度

$Q b\left(\mathrm{mgO} 2 / \mathrm{m}^{2} / \mathrm{hr}\right)$ : バックグラウンドの酸素消費速度

図-13 に夏季, 冬季の酸素消費速度 $Q$ を示寸. 酸素消費 速度は夏季と冬季で大きく異なり，水温が高い夏季は低 圧処理土を用いた E1，E2 で 100〜 $160 \mathrm{mgO} 2 / \mathrm{m}^{2} / \mathrm{hr}$ を示し たのに対し, 砂質土の $\mathrm{E} 3$ および天然干潟の C2 は 50〜 $60 \mathrm{mgO} 2 / \mathrm{m}^{2} / \mathrm{hr}$ と半分以下の速度であった。この結果は, 低圧処理土を用いた人工干潟の底質が，ベントスにより 活発に酸化分解されていることを示している.

\section{b) 栄養塩類の溶出量}

図-14，図-15 に海底に 4 時間にわたり静置したアクリ ルコア内における TN，TP のフラックス(面積/日あたり) を示す.フラックスは現地海水中の濃度を初期濃度とし, 4 時間後のアクリルコア内の濃度との差から算出した.

夏季の TN フラックスより, 実験区 E1，E2，E3 では底 質から直上水に窒素が供給されていた。 しかし, 冬季の フラックスは非常に小さかった。 TP フラックスは, 夏 季は TN と同様に実験区 E1，E2，E3 で増加したが，冬 季は減少した. この結果, 夏季は底質から直上水へリン が供給され，冬季は逆に底質へリンが供給された. 夏季

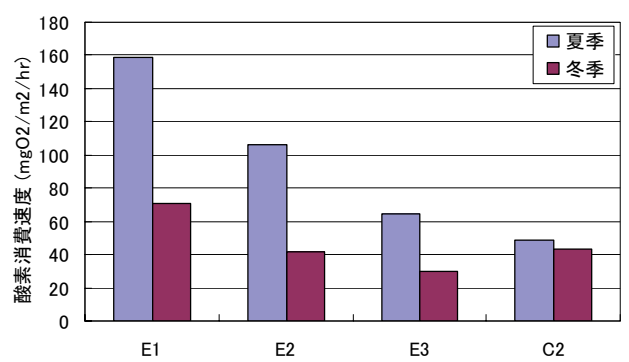

図-13 干潟底質の酸素消費速度

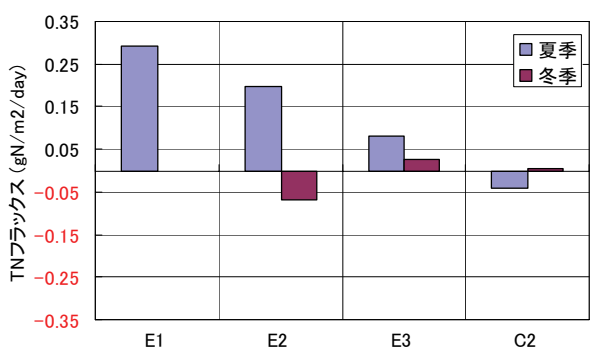

図-14 TNフラックス
における TN, TP の溶出は, 水温の上昇に伴う生物の活 発な活動によることが予測できる.

\section{c) マクロベントス及びバクテリア}

表-6に $1 \mathrm{~m}^{2}$ あたりに換算して算出したチャンバー内に 出現した夏季のマクロベントスの湿重量及び個体数を,

図-16 にバクテリアの計数結果を示す. マクロベントス の湿重量は低圧処理土を用いた E1，E2 が砂質土の E3 及び天然干潟 C2 より多く, マクロベントスの活動によ る，底質・溶出成分・基礎生産への影響が予測された。 バクテリアのうち菌体細胞数を計測した全菌数, 有機物 を酸素を分解する好気性菌数は，全ての実験区で有為な 差はみられなかった。しかし，嫌気環境で脱窒素等を行 う嫌気性菌数は低圧処理土の E1，E2 で $10^{6}$ オーダーで あるのに対して, 砂質土の $\mathrm{E} 3$, 砂質土天然干潟 C2 が $10^{5}$ オーダーとなっており, 低圧処理土中の嫌気性菌数 が約 10 倍多量となる傾向を示した. この結果は, 低圧 処理土を用いた人工干潟におけるバクテリアによる好気 的な分解は砂質土の天然干潟と同等であり, 脱窒等の嫌 気的な分解能力がわずかであるが高いことが考えられた.

\section{(4) 浄化機能}

\section{a) 栄養塩の形態と溶出挙動}

水中での栄養塩(窒素・リン)の形態と分析法を図-17 に示す．また，アクリルコアを海底に設置してから 4 時 間後の TN(DTN，PON)および TP(DTP，POP)の初期水と

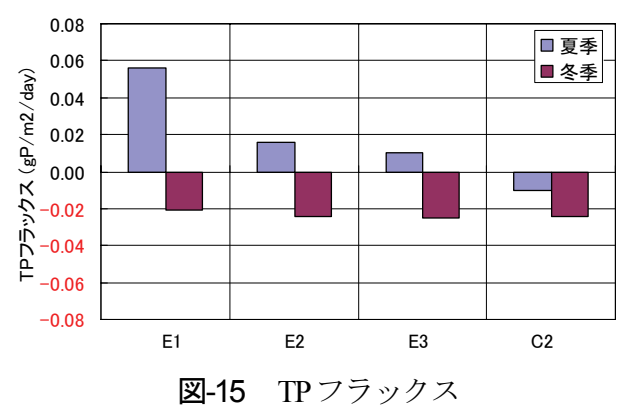

表-6 マクロベントス計測結果(夏季)

\begin{tabular}{ccccc}
\hline & E1 & E2 & E3 & C2 \\
\hline 湿重量 $\left(\mathrm{g} / \mathrm{m}^{2}\right)$ & 527 & 169 & 27 & 89 \\
\hline 個体数 $\left(\right.$ (個体 $\left./ \mathrm{m}^{2}\right)$ & 35 & 12 & 22 & 24 \\
\hline
\end{tabular}

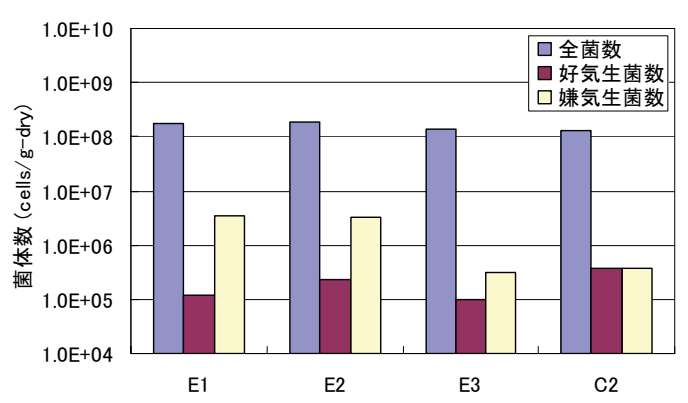

図-16 バクテリア計数結果(夏季) 
の濃度の差(溶出濃度)を図-18, 図-19 に，底質表層土の 間隙水中の DTN，DTP を図-20，図-21 に示す. 図-14に 示したように E1，E2，E3 では TN が増加しているが, 窒素の溶出形態を詳細に検討すると, 図-18 に示すよう に特に E1，E2 では溶存態だけでなく粒子態(PON)とし て存在していることがわかる. TP でも E1 では粒子態 (POP)が溶存態(DTP)の 10 倍以上高い濃度を示している これら低圧処理土を用いた E1，E2 に比べると，砂質土 $\mathrm{E} 3$ と砂質土天然干潟 $\mathrm{C} 2$ は溶出量が少ない. 間隙水中の DTN 濃度を図-20 に示す。低圧処理土を用いた実験区の うち $\mathrm{E} 2$ が約 3.0mgN/l であるのに対して, E1 では E3, $\mathrm{C} 2$ に満たない DTN 濃度である. これらの結果から，ア クリルコア内の窒素, リン濃度の増加は, 底質の間隙水 中からの溶出だけでなく, マクロベントスによる撹乱等 の他の要因によることが予測できる.

\section{b) 栄養塩の収支}

干潟の底質と直上水間の窒素，リンの関係を図-22 に 示す.アクリルコアの直上水で計測される粒子状物質量 は，沈降量とマクロベントスの撹乱による再懸濁や排泄 との差であり, 溶存物質濃度は底生藻類による吸収とマ クロベントスの排泄の差である. したがって水中の窒素 及びリンはマクロベントス量により変動すると考えるこ

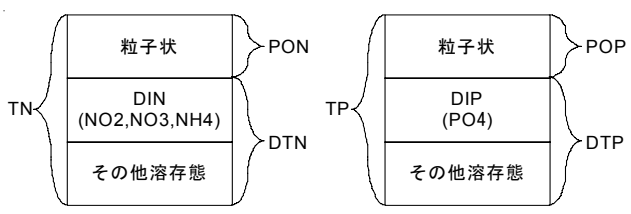

$\mathrm{TN}, \mathrm{TP}$ ： 試料を直接分析

DTN,DTP：WatmanGF/Fにてろ過した試料を分析

$\mathrm{DIN}$ : $\quad \mathrm{NO2,NO3,NH4}$ を個別分析

DIP : PO4 として分析

図-17 窒素・リンの形態

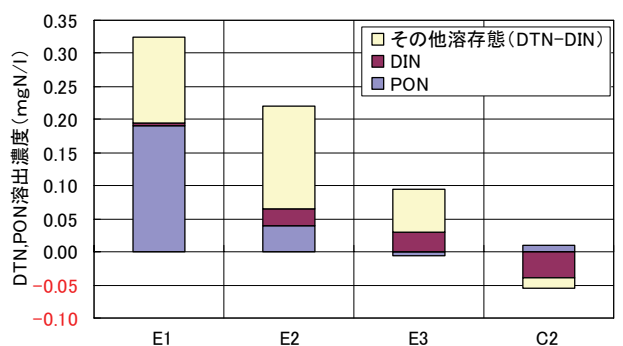

図-18 DTN，PON溶出量

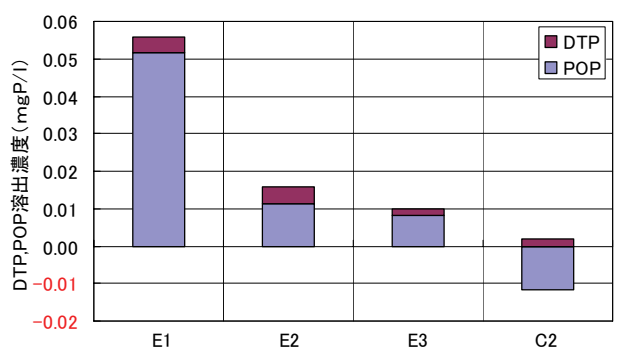

図-19 DTP，POP溶出量
とができる，そこで，図-23に $1 \mathrm{~m}^{2}$ あたりに換算したマ クロベントス湿重量(表-6)と直上水の粒子状物質(PON, $\mathrm{POP})$ の関係を示す。 マクロベントス湿重量と, これら の粒子状物質濃度には正の相関がみられ, 直上水の栄養 塩濃度が底生生物量に依存していることを示している. この結果をもとに算定した底質と直上水間の PON, POP フラックスを図-24 に示す. 正のフラックスは底質から の供給を, 負のフラックスは底質におけるトラップを示 す. 低圧処理土を用いた実験区 E1，E2 のうち，マクロ ベントス湿重量が最も多い E1 のフラックスは，PON ; $0.16 \mathrm{gN} / \mathrm{m}^{2} /$ day, POP $; 0.05 \mathrm{gN} / \mathrm{m}^{2} /$ day となり, 粒状化処理 をした E2の 3 倍に達した. 一方, 砂質土の E3, 砂質土 天然干潟 C2 では, 粒子状物質のフラックスはほとんど 見られなかった.このような粒子状物質の移動は，一見 すると豊富な栄養塩を含む浚渫へドロを混合した低圧処 理土からの溶出と見られるが，図-20, 図-21 示す底質間 隙水中の DIN, DIP 濃度との相関はみられない. この結 果は，底質表層付近に存在するマクロベントスによる底 質の擋乱・排泄によると考えられる.

\section{c) 基礎生産量}

低圧処理土を用いた人工干潟では，干潟表層のマクロ ベントス量に依存した粒子状物質の直上水への供給がな されることが明らかになった. マクロベントスの活動に は酸素が必須である，そこで，干潟底質における付着性 藻類による基礎生産に関する評価を行った，基礎生産量 は明暗条件のチャンバーで計測した酸素増減量を元に以 下の方法を用いて算出した．暗条件下での DO は底質の 酸素消費のみを計測した值であり，明条件下で計測され る DOは, 藻類の光合成で生産される基礎生産量から,

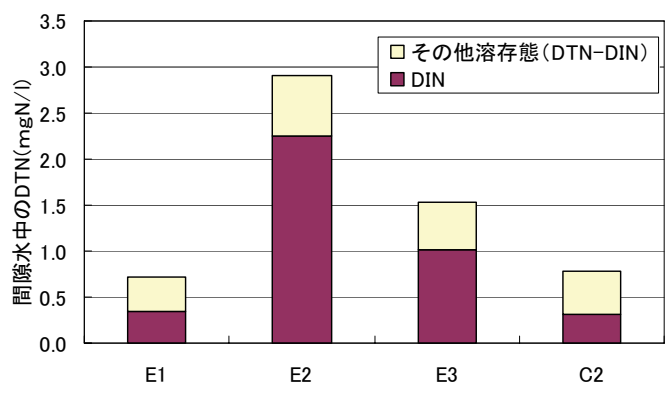

図-20 底質間隙水中の DTN 濃度

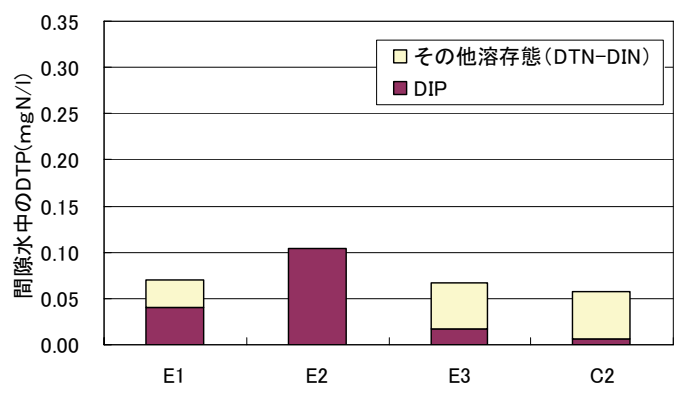

図-21 底質間隙水中の DTP 濃度 


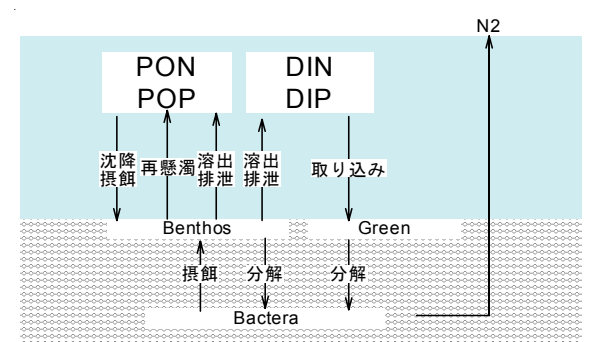

図-22 干潟域における栄養塩の収支

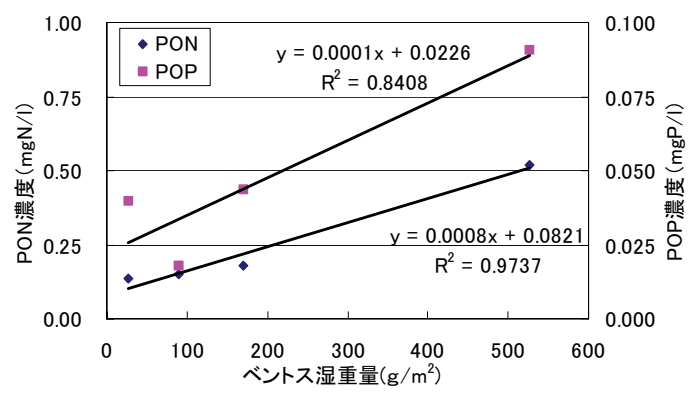

図-23 マクロベントス湿重量と粒子状物質濃度の関係

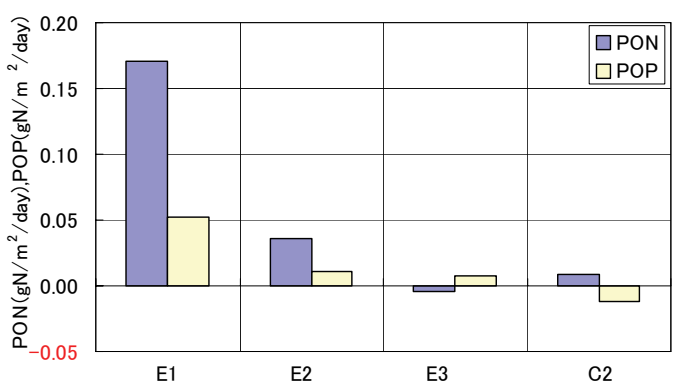

図-24 底質と直上水間の PON，POPフラックス

底質で消費される酸素消費量を差し引いた值である。

図-25に基礎生産量を元に算出した単位面積あたりの基 礎生産速度を示す．夏季の基礎生産速度は，いずれの実 験区，対象区，天然干潟ともに冬季に比心゙高く，低圧処 理土を用いた E1 では夏季に $200 \mathrm{mgO} / \mathrm{m}^{2} / \mathrm{hr}$ と最も高くな った。 これは天然の干潟である C2 の約 1.5 倍以上の基 礎生産速度であり，付着性藻類が多量に存在しているこ とを示している。

\section{(5) 干潟の浄化機能}

低圧処理土を用いた資源循環型の人工干潟は，豊富な 栄養塩を含有し，多種多様なマクロベントスの生息場所 を提供していることが詳細な調査により明らかとなった。 図-26 に基礎生産速度と酸素消費速度の結果を併せて示 した．低圧処理土の人工干潟(E1，E2)は対象区 E3 や天 然干潟 $\mathrm{C} 2$ に比べ基礎生産速度，酸素消費速度ともに高 くなった。この結果は，低圧処理土の人工干潟で付着性 藻類による酸素の供給とマクロベントスやバクテリアに よる酸素消費が活発に行われていることを示している. 第 2 章で示したように，低圧処理土の人工干潟(E1，E2) は，対象区 E3，天然干潟 C2 に比べ栄養塩の含有量が高

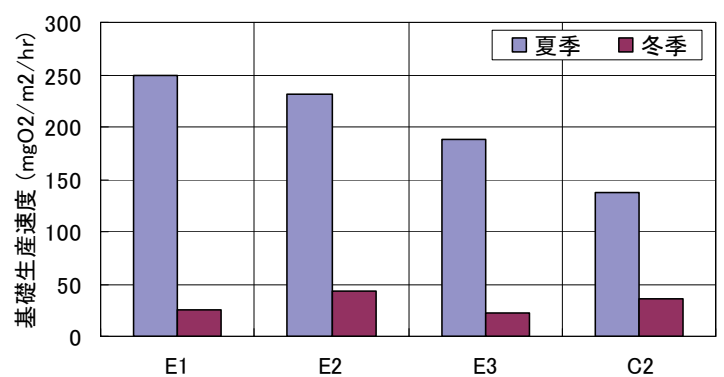

図-25基礎生産速度

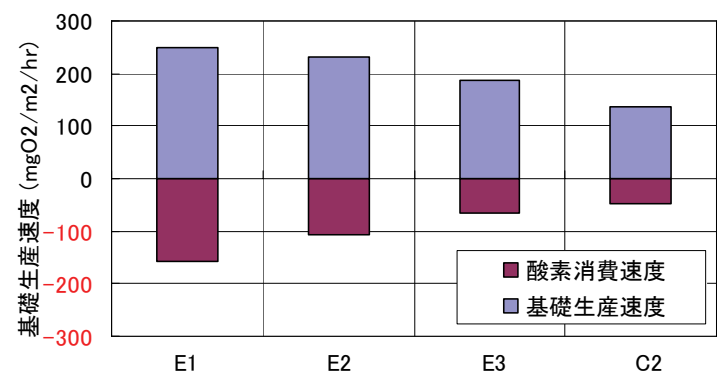

図-26 基礎生産速度と酸素消費速度

い状態を施工直後から保ち続けている。したがって，低 圧処理土を用いた人工干潟では底質から供給される豊富 な有機物を供給源として, 付着性藻類による酸素供給と 付着藻類を摂慨するマクロベントスの増加，マクロベン トスとバクテリアによる活発な有機物の酸化分解が行わ れていると考えられる。

干潟では水中への酸素供給，ベントスによる栄養塩の ストック，底質における有機物の酸化分解が行われ，こ れらがバランスして水質浄化を果たす 1),11. 低圧処理土 を用いた資源循環型の人工干潟は，付着性藻類やマクロ ベントスが多量に生息する場を提供し，より多くの酸素 を水中に供給する高い基礎生産と，有機物を分解する高 い酸素消費が行われている。これらの結果より，資源循 環型人工干潟への低圧処理土の利用は，高い浄化機能を 持つ沿岸環境の構築が可能で，沿岸域の環境改善に寄与 できると考えられる.

\section{5. 結論}

本研究の主要な結論を以下に示寸.

(1) 浚渫へドロの固液分離方法として従来の高圧処理に 代わる低圧処理方式で固液分離するシステムを開発 した．本システムで処理した低圧処理土は，高圧処 理土に比べ軟弱であるが，資源循環型人工干潟への 利用を目的とする場合，砂質土と混合した低圧処理 土は均一に分散し，実海域海底で長期間にわたり安 定した栄養塩濃度を維持することが明らかになった。 （2）低圧処理土の粒状化処理は，脱水ケーキを移動する 
際にハンドリングが向上するとともに，干潟土壌と してシルト粘土含有率，底質 COD がより安定した 状態で維持できることが可能であった.

(3) 低圧処理土を用いた資源循環型の人工干潟ではマク ロベントス個体数，種類数は天然干潟や砂質土の人 工干潟と同等であり，特に大型の生物種が定着しや すい環境を創出できる.

（4）低圧処理土を用いた人工干潟について，底質と直上 水における基礎生産力，栄養塩類，マクロベントス に着目した詳細な調査を行った結果，多量のマクロ ベントスの定着と高い基礎生産力をもつ，浄化能力 の高い環境を構築できることを確認した.

沿岸域における水質悪化を改善する目的で，各地で人 工干潟の造成が行われている. 資源循環型人工干潟は, 浚渫事業による沖合いの海底環境の改善と, 沿岸域の高 い浄化能力をもつ干潟造成を同時に行うものであり，沿 岸域の水域環境の改善に適した工法である.さらに資源 循環型人工干潟の造成に低圧処理土を用いることは，浚 渫へドロの固液脱水処理コストを削減するだけでなく, 砂質土の人工干潟に比べ，高い浄化能力を有する環境を 創出し，沿岸域の環境改善に利用できることを，現地実 験を通して検証した.

謝辞 : 本研究は三重県地域結集型共同研究事業の一部で 実施された。現地実験にあたり志摩市，志摩の国漁協立 神支所，芙蓉海洋開発(株)から多大な協力を得た. ここ に謝意を表す.

\section{参考文献}

1) 海の自然再生ワーキンググループ : 海の自然再生ハンドブ ック，第 2 巻, pp. 15-19, 2004.

2）国分秀樹，奥村宏征，上野成三，高山百合子，湯浅城之： 英盧湾における浚渫へドロを用いた干潟造成実験から得ら れた干潟底質の最適条件, 海岸工学論文集, 51 巻, pp.11911195,2004

3) 岡田光正 : 干潟・藻場の創出ならびに保全に関するバイオ レメディエーション技術，第 27 回環境保全・公害防止研究 発表会講演要旨集, pp. 9-11,2000.

4）国分秀樹，奥村宏征，上野成三，高山百合子，湯浅城之： 英盧湾における浚渫へドロを用いた大規模造成干潟の底質 と底生生物の特性について, 海岸工学論文集, 52 巻, pp.1196-1200, 2005.

5) 小林勲，今野昭三，岩崎光美 : 建設工事における濁水・泥 水の処理工法, pp. 158-164, 鹿島出版会, 1995.

6) 片倉徳男, 上野成三，小林峯男，柴田隆宏，今井大蔵，村 上和男 : 浚渫へドロを用いた干潟造成を目的とした高効率な 浚渫底泥脱水技術の開発，海洋開発論文集，22巻，pp. 945-950， 2006.

7) 栗原康 : 河口・沿岸域の生態学とエコテクノロジー, pp. 51, 1988.

8）片倉徳男，高山百合子，上野成三，小林峯男，国分秀樹, 奥田圭一 : 浚渫へドロを用いた干潟再生工法におけるへド 口混合の設計・施工計画, 海洋開発論文集, 21 巻, pp.885$890,2005$.

9) 上野成三，高橋正昭，原条誠也，高山百合子，国分秀樹 : 浚渫へドロを利用した資源循環型人工干潟の造成実験，海 岸工学論文集, 48 巻, pp. 1306-1310， 2001.

10）上野成三，高橋正昭，高山百合子，国分秀樹 : 浚渫土を用 いた干潟再生実験における浚渫土混合率と底生生物との関 係について, 海岸工学論文集, 49巻, pp. 1301-1305， 2002.

11) 国分秀樹, 高山百合子 : 干潟の特徵と再生実験, 海洋と生 物, Vol.30, No.3,pp.303-313，2008.

(2009.5.28 受付)

\section{INSPECTION OF THE EFFECT TO IMPROVE THE ENVIRONMENT OF THE ARTIFICIAL TIDAL FLAT THAT USED THE SOIL DEWATERED BY LOW PRESSURE}

\section{Norio KATAKUARA, Kazuo MURAKAMI, Daizo IMAI and Hideki KOKUBU}

An artificial formation of tidal flat is developed to keep the environment of the area along the shore. A new method to develop for an artificial tidal flat circulating resource is suggested. This new method mixes the sand of the shore and dewatered sludge. An artificial tidal flat of 7,200 square meters was developed with this new method at Ago-Bay in Mie prefecture. Authors developed a system of new processing that dehydrates from sludge by low pressure. This report is the result that examined utility to use soil treated by a new processing system to the artificial tidal flat circulating resources. The experiment was carried for 32 months. The experiment investigated a physical characteristic of the bottom soil and the habitation quantity of the benthos. In addition, we evaluated the environmental improvement effect of the artificial tidal flat. We confirmed a lot of benthos and high primary production in the artificial tidal flat that circulated resources. 